\title{
Electronic Government Development Strategies Using Frameworks COBIT 5
}

\author{
Fanny Novianto \\ Informatics Department, Faculty of Science and Technology, UIN Sunan Kalijaga, \\ Jl. Marsda Adisucipto No 1 Yogyakarta 55281, Indonesia. \\ Tel. +62-274-540971, Fax. +62-274-519739. \\ Email: fannynovianto@yahoo.co.id
}

\begin{abstract}
At this time, Information technology in the government or called by electronic government (e-government) is an absolute necessity and must be continuously developed as an acceleration tool in strategic policy and decision making. Utilization of e-government aims to improve performance and productivity, improve budget efficiency, transparency and accountability in the delivery of service activities to the communities. The incessant use of e-government in the government both central and regional, of course, not only produces benefit or value to the organization, but also gives a variety of problems and obstacles. To guarantee the benefit and value by using e-government and minimize various problems and obstacles, it is necessary to build information technology governance in the egovernment development. In the information technology governance, an organization does not only build information technology facilities and infrastructure, but how information technology is used be able to achieve organizational goals, is able to play a role in the organization's strategic decision making processes and policies and remains in harmony with the architecture framework of information technology development that is has been established. To achieve information technology good governance, strategies are needed in developing existing e-government. The first step is to evaluate the implementation of e-government. Evaluation is done by measuring the level of maturity of e-government that has been applied. This measurement includes a strategic plan for information technology management, maintenance of information technology facilities and infrastructure, management of information technology services that are sustainable and the last is oversight of information technology governance. The scope of this research is e-government which has been implemented in the Ministry of Law and Human Rights in the Special Region of Yogyakarta. The research method used is a quantitative method using a questionnaire instrument and using the 5th edition of the Control Objective for Information and Related Technology (COBIT) framework model to determine the level of maturity in the information technology governance process. This study will provide an overview of information technology governance has been implemented and produce recommendations that is needed to improve and develop a comprehensive information technology governance.
\end{abstract}

Keywords: e-government, framework COBIT 5, information technology governance, maturity model.

Abbreviations: electronic government (e-government), Correctional Database System (SDP), Control Objective for Information and Related Technology (COBIT)

\section{INTRODUCTION}

Information technology has become an important element in the industrial era 4.0, an era where the concept of automation is known in the production process carried out by technology by reducing the role of humans in its application. The hope of this concept is to reduce the risk of failure, improve the accuracy and efficiency of time at work. This concept can be applied to the industrial, education, health and government sectors. At this time, Information technology in the government or called by electronic government (egovernment) is an absolute necessity and must be continuously developed as an acceleration tool in strategic policy and decision making. Utilization of egovernment aims to improve performance and productivity, improve budget efficiency, transparency and accountability in the delivery of service activities to the communities.

Since the issuance of Presidential Instruction Number 3/2003 concerning about National Policies and Strategies for E-Government Development, both central governmet and local governments, have begun to move to develop e-government in their respective regions. The application of e-government in government aims to break down long and rigid bureaucratic barriers that hinder interaction between institutions and inhibit partnerships with the business world and open up space for people to participate in developing the nation and state.

Initially the implementation of e-government was slow, starting with the use of websites in government offices as a source of information for the public. The slow development of e-government is because to build information technology facilities and infrastructure requires enormous investments, human resources as managers of information technology experience a transition from traditional serving culture through face to face, long bureaucracy into a culture that is expected to be fast, transparent and accurate and regulation as a legal standing in the implementation of standardized egovernment has not been sufficient. At 2011, all central 
and local governments, including ad-hoc institutions, had websites. (Onno W Purbo. 2011)

The incessant use of e-government in the government both central and regional, of course, not only produces benefit or value to the organization, but also gives a variety of problems and obstacles. To guarantee the benefit and value by using e-government and minimize various problems and obstacles, it is necessary to build information technology governance in the e-government development. In the information technology governance, an organization does not only build information technology facilities and infrastructure, but how information technology is used be able to achieve organizational goals, is able to play a role in the organization's strategic decision making processes and policies and remains in harmony with the architecture framework of information technology development that is has been established.

The Ministry of Law and Human Rights of the Republic of Indonesia is currently implementing egovernment in internal business processes and public services. Various innovations have been carried out by the Ministry of Law and Human Rights of the Republic of Indonesia to develop e-government that aimed at serving prime communities, eliminating illegal payments and creating transparent and accountable performance. One of them is the use of the Correctional Database System (SDP).

SDP a comprehensive Information Technology solution that covers all Correctional business processes. SDP is defined as the entire information system which includes the collection, screening, management, presentation, and communication of Correctional information. SDP management is a managerial, operational and special implementation activity that involves crossing relevant work units to ensure the implementation of the SDP under the coordination of the Directorate General of Corrections. The Prison-Based Citizens Database can be used as material for consideration in the formulation of prisons or detention policies, availability of reliable personnel in the operation of the SDP Application, availability of reports, information, letters and prisons and detention policies, compilation of data, reports, inputs at the Directorate General of Corrections, availability of Prison-Based Citizen fingerprint database and their families, availability of the National Recidivis Identification Function.

To achieve information technology good governance, strategies are needed in developing existing egovernment. The first step is to evaluate the implementation of e-government. Evaluation is done by measuring the level of maturity of e-government that has been applied. This measurement includes a strategic plan for information technology management, maintenance of information technology facilities and infrastructure, management of information technology services that are sustainable and the last is oversight of information technology governance.

The scope of this research is e-government which has been implemented in the Ministry of Law and Human Rights in the Special Region of Yogyakarta. The research method used is a quantitative method using a questionnaire instrument and using the 5th edition of the Objective for Information and Related Technology (COBIT) framework model to determine the level of maturity in the information technology governance process. This study will provide an overview of information technology governance has been implemented and produce recommendations that is needed to improve and develop a comprehensive information technology governance.

\section{MATERIALS AND METHODS}

\section{Study area}

E-government is a system for the administration of government by utilizing information and communication technology, especially those relating to providing services to the public (M. Khoirul Anwar, Asianti Oetojo S. 2004). Changes in the presence of e-government are to improve governance structures that are more responsive, have a more effective and efficient process, achieve accountability and provide better services to the community. (D. Norris. 2008)

The benefits of implementing e-government as a governance media are as follows (Richardus Eko Indrajit. 2005):

a. Improving the quality of government services to stakeholders, especially in terms of performance effectiveness and efficiency in a variety of state life.

b. Increase transparency, control, and accountability in the administration of government

c. Significantly reduce total administration, relations and interaction costs incurred by the government and stakeholders for the needs of daily activities

d. Creating an atmosphere of the new community environment that can quickly and accurately answer various problems faced in line with various global changes and existing trends

e. Empowering the community and other parties as government partners in the process of making various public policies equally and democratically

E-government Maturity Model is a tool for evaluating to assess developments in the implementation of eGovernment. There are several e-Government evaluation methods that have been applied throughout the world and have had a significant impact on the implementation of e-government.

COBIT (Control Objective for Information and Related Technology) is an IT governance framework and supporting tool set that allows managers to bridge 
the gap between control requirements, technical issues and business risk. COBIT enables clear policy development and good practice for IT control throughout organisations. COBIT emphasises regulatory compliance, helps organisations to increase the value attained from IT, enables alignment and simplifies implementation of the COBIT framework. (ISACA. 2012)

COBIT 5 is a major strategic improvement providing the next generation of ISACA guidance on the governance and management of enterprise information technology (IT) assets. Building on more than 15 years of practical application, ISACA designed COBIT 5 to meet the needs of stakeholders, and to align with current thinking on enterprise governance and management techniques as they relate to IT.

The COBIT 5 principles and enablers are generic and useful for enterprises of all sizes, whether commercial, not-for-profit or in the public sector.

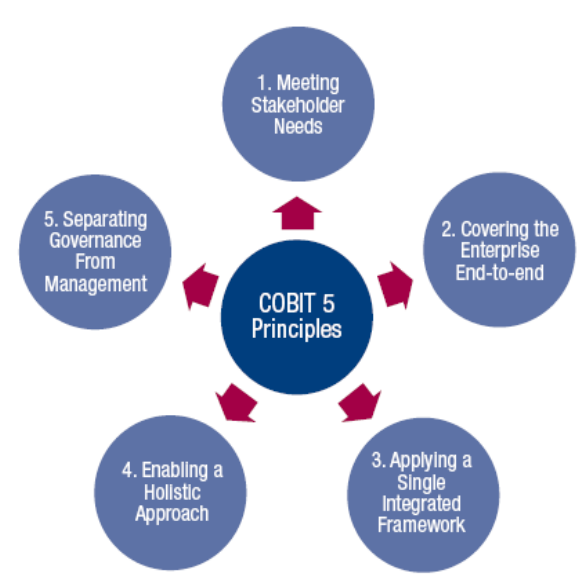

Figure 1. The COBIT 5 Principles

1. Meeting Stakeholder Needs;

Governance is about negotiating and deciding amongst different stakeholders' value interests. The governance system should consider all stakeholders when making benefit, resource and risk assessment decisions.

2. Covering the Enterprise End-to-end;

Integrates governance of enterprise Information Technology into enterprise governance, the governance system for enterprise Information Technology proposed by COBIT 5 integrates seamlessly in any governance system because COBIT 5 aligns with the latest views on governance. Covers all functions and processes within the enterprise and COBIT 5 does not focus only on the 'Information Technology function', but treats information and related technologies as assets that need to be dealt with just like any other asset by everyone in the enterprise.
3. Applying a Single Integrated Framework; COBIT 5 aligns with the latest relevant other standards and frameworks used by enterprises. This allows the enterprise to use COBIT 5 as the overarching governance and management framework integrator.

4. Enabling a Holistic Approach;

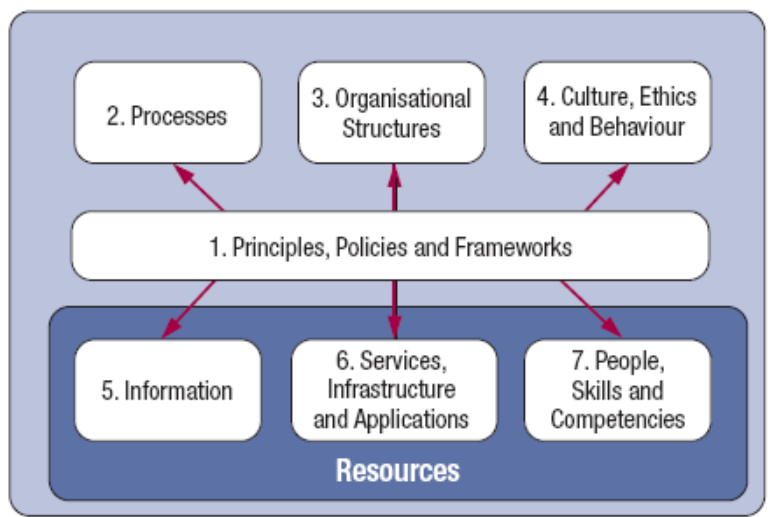

Figure 2. Enabling a Holistic Approach.

5. Separating Governance from Management;

Governance ensures that stakeholders needs, conditions and options are evaluated to determine balanced, agreed-on enterprise objectives to be achieved, setting direction through prioritisation and decision making and monitoring performance and compliance against agreed on direction and objectives (EDM). Management plans, builds, runs and monitors activities in alignment with the direction set by the governance body to achieve the enterprise objectives (PBRM).

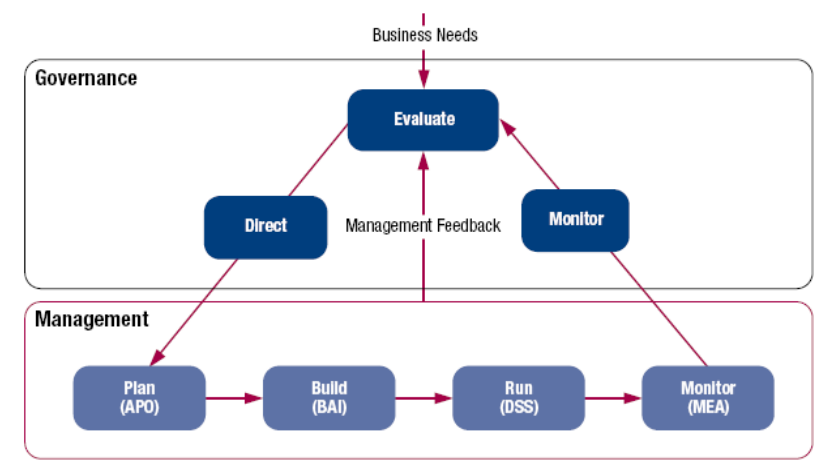

Figure 3. Separating Governance from Management.

\section{COBIT Process Domain 5}

The COBIT 5 process model divides the process of corporate governance and IT management into two process domains, namely:

1. Governance, The domain area contains 5 governance processes in the form of Evaluate, Direct, Monitor process domains. Where there is a definition for each process. 
2. Management, The domain area contains 4 domains, aligned with the area of responsibility of Plan, Build, Run, and Monitor (PBRM), providing end-to-end IT coverage. The domain is the structure of the COBIT 5 domain and process:

a). Align, Plan, and Organize (APO), Domain that discusses plans, strategies, and focus on achieving business objects. The realization of the vision strategy is needed to be planned, communicated and managed to produce perspective.

b). Build, Acquire, and Implement (BAI), Providing solutions and services that can be used. To realize the information technology strategy, the technological solutions needed, built or obtained, or already implemented must be in accordance with the business object.

c). Deliver, Service, and Support (DSS), Domain that discusses the delivery and support of services needed, including operational facilities, user service support and security management.

d). Monitor, Evaluate, and Assess (MEA), Observe all processes to ensure following the directions provided. All information technology processes are needed to be assessed at all times in order to maintain quality and fulfillment of control needs. The domain includes management performance, monitoring internal control, relating to governance.

\section{COBIT 5 Process Capability Model}

The assessment task in COBIT 5 is based on ISO/IEC 15504 underlining the strong alignment of this framework with the most generally accepted best practices and standards. The six levels of the COBIT 5 Process Capability Model are (Titus Kristanto et al. 2016):

1. Level 0: Incomplete process

The process is not placed or it cannot reach its objective. At this level the process has no objective to achieve. For this reason this level has no attribute.

2. Level 1: Performed process.

The process is in place and achieves its own purpose. This level has only "Process Performance" as process attribute.

3. Level 2: Managed process.

The process is implemented following a series of activities such as planning, monitoring and adjusting activities. The outcomes are established, controlled and maintained. This level has "Performance Management" and "Work Product Management" as process attributes.

4. Level 3: Established process.

The previous level is now implemented following a defined process that allows the achievement ofthe process outcomes. This level has "Process Definition" and "Process Deployment" as process attributes.
5. Level 4: Predictable process.

This level implements processes within a defined boundary that allows the achievement ofthe processes outcomes. This level has "Process Management" and "Process Control" as process attributes.

6. Level 5: Optimising process.

This level implements processes in the way that makes it possibletoachieve relevant,current and projected business goals. This level has "Process Innovation" and "Process Optimisation" as process attributes.

Table 1. Process Capability Model.

\begin{tabular}{lcl}
\hline Maturity Scale & Capability Value & Capability Level \\
\hline $0,00-0,50$ & Level 0 & Incomplete Process \\
$0,51-1,50$ & Level 1 & Performed Process \\
$1,51-2,50$ & Level 2 & Managed Process \\
$2,51-3,50$ & Level 3 & Established Process \\
$3,51-4,50$ & Level 4 & Predictable Process \\
$4,51-5,00$ & Level 5 & Optimizing Process \\
\hline
\end{tabular}

\section{Procedures}

In this research, the stages used are as follows:

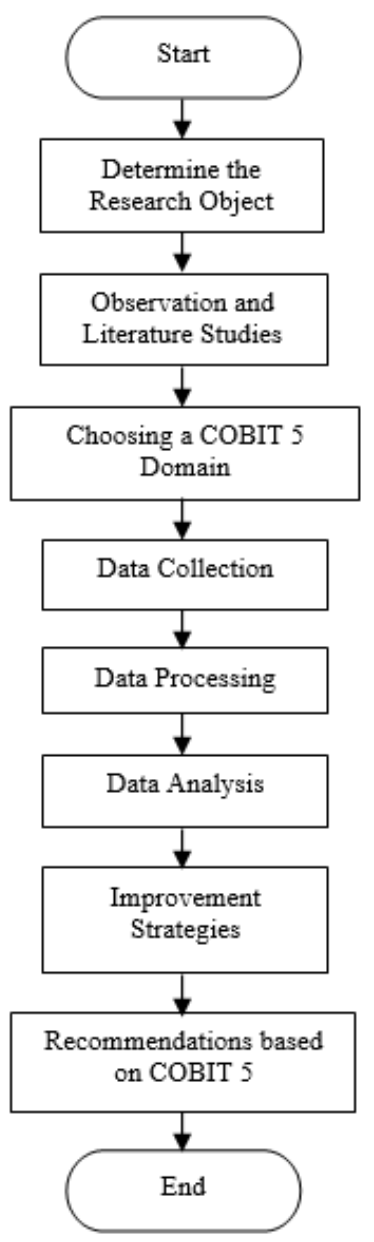

Figure 4. Procedures. 
1. Determine the Research Object, this research was conducted on the Correctional Database System at the Regional Office of the Ministry of Law and Human Rights in the Special Region of Yogyakarta;

2. Observation and literature studies are carried out for information about theories, concepts, methods that are appropriate to the problem;
3. Choosing a COBIT 5 Domain that is deemed appropriate to the problem;

In this research, the selected domains are:

Table 2. COBIT 5 Domain.

\begin{tabular}{|c|c|c|c|c|}
\hline No & \multicolumn{2}{|r|}{ Domain } & \multicolumn{2}{|r|}{ Practice } \\
\hline 1 & \multirow{5}{*}{ Governance } & \multirow{5}{*}{ Evaluate, Direct and Monitor } & EDM01 & Ensure Governance Framework Setting and Maintenance \\
\hline 2 & & & EDM02 & Ensure Benefits Delivery \\
\hline 3 & & & EDM03 & Ensure Risk Optimisation \\
\hline 4 & & & EDM04 & Ensure Resource Optimisation \\
\hline 5 & & & EDM05 & Ensure Stakeholder Transparency \\
\hline 6 & \multirow{8}{*}{ Management } & \multirow{4}{*}{ Align, Plan and Organise } & APO01 & Manage the IT Management Framework \\
\hline 7 & & & APO04 & Manage Innovation \\
\hline 8 & & & APO07 & Manage Human Resources \\
\hline 9 & & & APO13 & Manage Security \\
\hline 10 & & \multirow{3}{*}{ Deliver, Service and Support } & DSS01 & Manage Operations \\
\hline 11 & & & DSS04 & Manage Continuity \\
\hline 12 & & & DSS05 & Manage Security Services \\
\hline 13 & & Monitor, Evaluate and Assess & MEA02 & Monitor, Evaluate and Assess the System of Internal Control \\
\hline
\end{tabular}

4. Data collection in the form of observations made by directly observing the activities carried out and through the distribution of questionnaires with statements about the level of maturity that must be answered by the target. In the questionnaire has an alternative assessment, as follows: Strongly Agree, Agree, Neutral, Disagree and Strongly Disagree;

5. The selected respondent is the manager of the Correctional Database System, with the following levels:

a). Operator: Staff related to the Correctional Database System

b). Supervisor: Head of Sub Division that handles the Correctional Database System

c). Administrator: Head of Sub Division or Staff who handle Information Technology

6. Data processing by collecting and compiling in accordance with predetermined domains.

7. Data analysis is performed after data processing, consisting of capability analysis, expected capability level and gap analysis;

8. Improvement Strategies;

9. Recommendations based on COBIT 5 domain.

\section{Data analysis}

Data analysis is carried out by processing each questionnaire statement from respondents regarding the maturity level of the Correctional Database System.
Calculation of the level of maturity of each statement in the process at COBIT 5 uses a Likert Scale modification. The analysis includes the current capability analysis, expected capability analysis and gap analysis.

Table 3. Likert Scale.

\begin{tabular}{lll}
\hline No & Likert Scale & Index \\
\hline 1 & Strongly Agree & 5 \\
2 & Agree & 4 \\
3 & Neutral & 3 \\
4 & Disagree & 2 \\
5 & Strongly Disagree & 1 \\
\hline
\end{tabular}

The formula used in the calculation:

$$
\text { Index }=\frac{\sum \text { Answer }}{\sum \text { Question }}
$$

An expected capability level is obtained from the Strategic Plan document of the Ministry of Law and Human Rights of the Republic of Indonesia 2015-2019 and the value of the capability level is obtained from level 0 to level 5 . The target is greater than the current capability level that will be a concern in the preparation of Information Technology.

A gap analysis is process that compares actual performance or results with what was expected or desired. The method provides a way to identify 
suboptimal or missing strategies, structures, capabilities, processes, practices, technologies or skills, and then recommends steps that will help the company meet its goals.

\section{RESULTS AND DISCUSSION}

\section{Expected Capability}

In accordance with the 2015-2019 Ministry of Law and Human Rights Strategic Plan document of the Republic of Indonesia, it is seen that efforts to build integrated, transparent and accountable information technology facilities and infrastructure. The use of the Correctional
Database System must be sustainable and continuously improved to achieve the organization's vision and mission, so that it can be concluded that the capability level expected to reach Level 5 (Optimized Process) or according to the maturity scale has a value of $4.51-5.00$.

\section{Results of Capability Level Measurement per Domain}

Based on the results of processing the questionnaire data distributed to the manager and person in charge of the Correctional Database System, the following assessment results are obtained:

\section{Evaluate, Direct and Monitoring (EDM) Domain}

Table 4. Evaluate, Direct and Monitoring Result.

\begin{tabular}{|c|c|c|c|c|c|}
\hline Domain & & Practice & Maturity Scale & Capability Value & Capability Level \\
\hline \multirow{5}{*}{$\begin{array}{c}\text { Evaluate, } \\
\text { Direct } \\
\text { and } \\
\text { Monitor }\end{array}$} & EDM01 & $\begin{array}{l}\text { Ensure Governance Framework Setting } \\
\text { and Maintenance }\end{array}$ & 4.50 & Level 4 & Predictable Process \\
\hline & EDM02 & Ensure Benefits Delivery & 4.41 & Level 4 & Predictable Process \\
\hline & EDM03 & Ensure Risk Optimisation & 4.25 & Level 4 & Predictable Process \\
\hline & EDM04 & Ensure Resource Optimisation & 4.25 & Level 4 & Predictable Process \\
\hline & EDM05 & Ensure Stakeholder Transparency & 4.08 & Level 4 & Predictable Process \\
\hline
\end{tabular}

- EDM01, Ensure Governance Framework Setting and Maintenance;

The capability value achieved in the EDM01 sub-domain is located at Level 4 (Predictable Process) where the Ministry of Law and Human Rights at this level has carried out an information technology process in accordance with the established limits to achieve the expected results.

The applicable regulations related to information technology are able to optimize the management of SDP. At this level, the SDP that have been developed have met the expectations of stakeholders, there is careful planning and implementation of good procedures in the management of SDP. To ensure that SDP management runs well, the Ministry of Law and Human Rights of the Special Region of Yogyakarta routinely carries out performance monitoring in the form of Monitoring and Evaluation of SDP implementation in the Work Unit. Not only that, the Directorate General of Corrections as an SDP developer also oversees the performance of SDP implementation in the region and as a supporter if there are obstacles in the application of SDP.

- EDM02, Ensure Benefits Delivery;

The capability value achieved in the EDM02 sub-domain is located at Level 4 (Predictable Process) where the Ministry of Law and Human Rights at this level has carried out an information technology process in accordance with the established limits to achieve the expected results.

At this level the Ministry of Law and Human Rights is able to maintain the quality of services within the SDP. The use of SDP in public services is able to provide optimal benefits for the community, especially the fulfillment of the human rights of Prisoners. The fulfillment of SDP facilities and infrastructure up to the Work Unit level certainly requires the use of a very large budget, but this Information Technology investment is comparable to the benefits obtained by the Ministry of Law and Human Rights to achieve organizational goals according to its vision and mission.

\section{- EDM03, Ensure Risk Optimisation;}

The capability value achieved in the EDM03 sub-domain is located at Level 4 (Predictable Process) where the Ministry of Law and Human Rights at this level has carried out an information technology process in accordance with the established limits to achieve the expected results.

The Ministry of Law and Human Rights is able to manage the risks posed by the use of SDP effectively and efficiently up to the Work Unit level. The facilities and infrastructure of SDP which were damaged can be resolved optimally, so that it does not interfere with performance at the Work Unit. 
- EDM04, Ensure Resource Optimisation;

The capability value achieved in the EDM04 sub-domain is located at Level 4 (Predictable Process) where the Ministry of Law and Human Rights at this level has carried out an information technology process in accordance with the established limits to achieve the expected results.

The limited amount of budget in fulfilling Information Technology infrastructure at the Ministry of Law and Human Rights does not make SDP fail in development, because SDP is a top priority in the development of Information Technology infrastructure. The Ministry of Law and Human Rights is also able to optimally manage SDP facilities and infrastructure, this cannot be separated from the continuous performance monitoring of the Work Unit.
- EDM05, Ensure Stakeholder Transparency;

The capability value achieved in the EDM05 sub-domain is located at Level 4 (Predictable Process) where the Ministry of Law and Human Rights at this level has carried out an information technology process in accordance with the established limits to achieve the expected results.

The creation of an effective communication process between the Ministry of Law and Human Rights at the regional and central levels with external stakeholders makes SDP counted nationally. Stakeholders have easy access to data and reports presented in the SDP. The reporting system in the SDP is very transparent and complete in accordance with the needs of each stakeholder.

\section{Align, Plan and Organise (APO) Domain}

Table 5. Align, Plan and Organise Result.

\begin{tabular}{|c|c|c|c|c|c|}
\hline Domain & & Practice & Maturity Scale & Capability Value & Capability Level \\
\hline \multirow{4}{*}{$\begin{array}{c}\text { Align, Plan } \\
\text { and } \\
\text { Organise }\end{array}$} & APO01 & Manage the IT Management Framework & 4.19 & Level 4 & Predictable Process \\
\hline & APO04 & Manage Innovation & 4.44 & Level 4 & Predictable Process \\
\hline & APO07 & Manage Human Resources & 4.29 & Level 4 & Predictable Process \\
\hline & APO13 & Manage Security & 4.13 & Level 4 & Predictable Process \\
\hline
\end{tabular}

- APO01, Manage the IT Management Framework; The capability value achieved in the APO01 sub-domain is located at Level 4 (Predictable Process) where the Ministry of Law and Human Rights at this level has carried out an information technology process in accordance with the established limits to achieve the expected results.

The Ministry of Law and Human Rights is able to integrate the Correctional Activities business processes that were originally in the form of manual activities into the Information Technology process through SDP. In the process of transitioning from a manual into an Information Technology process, of course there are various problems encountered. In this case the Ministry of Law and Human Rights is able to overcome and manage

\section{- APO04, Manage Innovation;}

The capability value achieved in the APO04 sub-domain is located at Level 4 (Predictable Process) where the Ministry of Law and Human Rights at this level has carried out an information technology process in accordance with the established limits to achieve the expected results.

The existing SDP which is currently the result of the development of the SDP which began in 2009 has undergone various changes. Innovations continue to be made by the Ministry of Law and Human Rights to develop SDP in accordance with the needs of the Work Unit. In the application of new innovations, the Ministry of Law and Human Rights appoints several regions as pilot projects to test innovations in the SDP and continue to be evaluated until they become services that are ready to be used in other Work Units.

\section{- APO07, Manage Human Resources;}

The capability value achieved in the APO07 sub-domain is located at Level 4 (Predictable Process) where the Ministry of Law and Human Rights at this level has carried out an information technology process in accordance with the established limits to achieve the expected results.

The regulation that oversees the SDP specifically regulates the human resources of the manager and person in charge of the SDP. In the regulations governed the duties, authority, sanctions for employees who manage SDP. In addition, the Ministry of Law and Human Rights regularly provides education and training, technical guidance and technical consultation in class directly and through teleconferences to improve the competence of SDP managers. The Ministry of Law and Human Rights is also evaluating the performance of SDP managers. Shifting positions or replacement of SDP managers will be made if there are obstacles in the management of SDP in the Work Unit. 
- APO13, Manage Security;

The capability value achieved in the APO13 sub-domain is located at Level 4 (Predictable Process) where the Ministry of Law and Human Rights at this level has carried out an information technology process in accordance with the established limits to achieve the expected results.
In the case of cyber security, the Ministry of Law and Human Rights has adopted standard cyber security procedures in Indonesia. Periodically the network security testing and evaluation process has been carried out in the SDP.

\section{Deliver, Service and Support (DSS) Domain}

Table 6. Deliver, Service and Support Result.

\begin{tabular}{clllll}
\hline Domain & & Practice & Maturity Scale & Capability Value & Capability Level \\
\hline \multirow{2}{*}{$\begin{array}{c}\text { Deliver, Service and } \\
\text { Support }\end{array}$} & DSS01 & Manage Operations & 4.22 & Level 4 & Predictable Process \\
\cline { 2 - 6 } & DSS04 & Manage Continuity & 4.38 & Level 4 & Predictable Process \\
\cline { 2 - 6 } & DSS05 & Manage Security Services & 4.29 & Level 4 & Predictable Process \\
\hline
\end{tabular}

- DSSO1, Manage Operations;

The capability value achieved in the DSS01 sub-domain is located at Level 4 (Predictable Process) where the Ministry of Law and Human Rights at this level has carried out an information technology process in accordance with the established limits to achieve the expected results.

In the business process of SDP management, the Ministry of Law and Human Rights ensures that the Standard Operating Procedures that have been set are always used, and there will be a review of procedures that require improvement. Monitoring and Evaluation of SDP facilities and infrastructure is routinely carried out in the Work Unit.

\section{- DSSO4, Manage Continuity;}

The capability value achieved in the DSS04 sub-domain is located at Level 4 (Predictable Process) where the Ministry of Law and Human Rights at this level has carried out an information technology process in accordance with the established limits to achieve the expected results.
Innovations in the SDP continue to be developed by the Ministry of Law and Human Rights, not only that, the addition of SDP infrastructure in the Work Unit that is directly related to service to the community continues to be carried out. This is a strategy undertaken by the Ministry of Law and Human Rights to ensure the sustainability of the SDP.

- DSS05, Manage Security Services;

The capability value achieved in the DSS05 sub-domain is located at Level 4 (Predictable Process) where the Ministry of Law and Human Rights at this level has carried out an information technology process in accordance with the established limits to achieve the expected results.

The Ministry of Law and Human Rights is able to manage and protect network and connectivity security. This is because the Ministry of Law and Human Rights has implemented cyber security standards in Indonesia. In addition, the Ministry of Law and Human Rights strictly regulates the access rights of SDP managers, monitors user identities and automatically records the activities of Human Resources using SDP.

\section{Monitor, Evaluate and Assess (MEA) Domain}

Table 7. Monitor, Evaluate and Assess Result.

\begin{tabular}{|c|c|c|c|c|c|}
\hline Domain & & Practice & Maturity Scale & Capability Value & Capability Level \\
\hline $\begin{array}{l}\text { Monitor, Evaluate } \\
\text { and Assess }\end{array}$ & MEA02 & $\begin{array}{l}\text { Monitor, Evaluate and Assess the } \\
\text { System of Internal Control }\end{array}$ & 4.22 & Level 4 & Predictable Process \\
\hline
\end{tabular}

- MEA02, Monitor, Evaluate and Assess the System of Internal Control;

The capability value achieved in the MEA02 sub-domain is located at Level 4 (Predictable Process) where the Ministry of Law and Human Rights at this level has carried out an information technology process in accordance with the established limits to achieve the expected results.

The Ministry of Law and Human Rights has implemented an internal control system on the 
application of the SDP in the Work Unit. Through Monitoring and Evaluation of SDP as a whole which is carried out by a Team from the central or regional to the Work Unit below it, in addition, an internal audit is conducted on SDP facilities as State Property.

\section{Gap Analysis}

Based on the current capability level analysis as a whole is at level 4 (Predictable Process), when compared to the expected capability level at level 5 (Optimizing Process), there is a gap of 1 level. When viewed from the level of maturity will be explained in the following table:

Table 7. Gap Analysis.

\begin{tabular}{|c|c|c|c|c|}
\hline \multirow[b]{2}{*}{ No } & \multirow[b]{2}{*}{ Domain } & \multicolumn{3}{|c|}{ Maturity Scale } \\
\hline & & Current & $\begin{array}{c}\text { Expected } \\
\text { (Max) }\end{array}$ & $\begin{array}{c}\text { Gap }= \\
\text { Expected- } \\
\text { Current }\end{array}$ \\
\hline 1 & EDM01 & 4.50 & 5.00 & 0.50 \\
\hline 2 & EDM02 & 4.41 & 5.00 & 0.59 \\
\hline 3 & EDM03 & 4.25 & 5.00 & 0.75 \\
\hline 4 & EDM04 & 4.25 & 5.00 & 0.75 \\
\hline 5 & EDM05 & 4.08 & 5.00 & 0.92 \\
\hline 6 & APO01 & 4.19 & 5.00 & 0.81 \\
\hline 7 & APO04 & 4.44 & 5.00 & 0.56 \\
\hline 8 & APO07 & 4.29 & 5.00 & 0.71 \\
\hline 9 & APO13 & 4.13 & 5.00 & 0.88 \\
\hline 10 & DSS01 & 4.22 & 5.00 & 0.78 \\
\hline 11 & DSS04 & 4.38 & 5.00 & 0.63 \\
\hline 12 & DSS05 & 4.29 & 5.00 & 0.71 \\
\hline 13 & MEA02 & 4.22 & 5.00 & 0.78 \\
\hline
\end{tabular}

The graphic maturity level of information technology governance in the Correctional Database System in the Ministry of Law and Human Rights in the Yogyakarta Special Region is as follows:

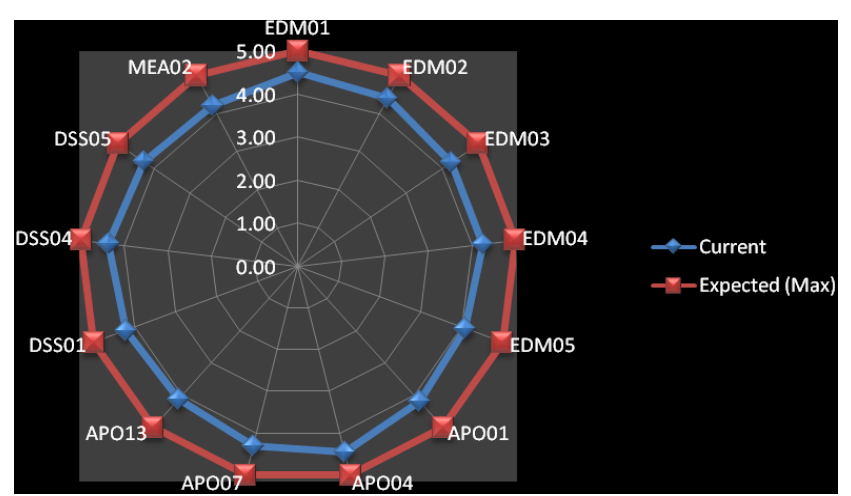

Figure 5. Gap Analysis Graphic based on Maturity Level.

\section{Discussion}

From the gap analysis based on the level of maturity, it can be seen that the gap between the current level of maturity and the expected level of maturity is not too large. This means that it is not too difficult for the Ministry of Law and Human Rights of the Special
Region of Yogyakarta to continuously develop and improve SDP Information Technology governance to achieve organizational goals and for future needs.

Recommendations given refer to the results of the capability level and gap analysis and can be used as a strategy in developing and optimizing SDP Information Technology governance:

a. Performance monitoring through comprehensive monitoring and evaluation of Information Technology governance in the Work Unit by involving Teams from the regions and Teams from the center as supporters;

b. Involving the community in developing SDP through data and information obtained from the dissemination of community satisfaction surveys;

c. Optimizing existing regulations related to the exchange of data and information between law enforcement agencies and increasing synergy between law enforcement agencies by immediately implementing the integration of Information Technology services;

d. Addition of employees who have competence in the field of Information Technology through the recruitment of new employees or contract employees;

e. Open space for employees in the Work Unit who are competent in the field of Information Technology to innovate that can benefit the organization;

f. Increasing the competency of existing employees in the region through structured education and training, through technical guidance and online technical consultation and then forming a regional helpdesk team that helps with the tasks of the central supporting team;

g. Propose to change the status of the SDP managerial position to a specific functional position that impacts on improving employee welfare.

\section{REFERENCES}

D. Norris. 2008. E-government Research: Policy and Management. Igi Publishing, New York.

ISACA. 2012. A Business Framework for the Governance and Management of Enterprise IT. Rolling Meadows, USA.

M.Khoirul Anwar, Asianti Oetojo S. 2004. Management Information Systems for Government in the Era of Regional Autonomy (SIMDA). Yogyakarta: Pustaka Pelajar.

Onno W Purbo. 2011. Indonesian Internet History: e-government. www.lms.onnocenter.or.id/wiki.

Richardus Eko Indrajit. 2005. E-Government in Action. Andi, Yogyakarta.

Titus Kristanto et al. 2016. Analysis of E-government Maturity Level Using Framework Cobit 5 (Case Study: Department of Trade and Industry Surabaya City), East Java. Researchgate. 
THIS PAGE INTENTIONALLY LEFT BLANK 